\author{
O.A. Golovanova, K.K. Golovchenko \\ F.M. Dostoevsky Omsk State University, Russia \\ (E-mail: golovanoa2000@mail.ru)
}

\title{
Physicochemical regularities of the sorption of amino acids on the surface of brushite
}

\begin{abstract}
Calcium phosphates are part of biogenicand pathogenic mineral formations. Brushite occurs mainly in conjunction with other calcium phosphates in the composition of pathogenic mineral formations in the body of animals and humans. There are a number of assumptions, according to which the basis of the processes of mineralization is the adsorption interaction of free amino acids and associated protein molecules with inorganic components of biological liquids. However, the mechanism of their interaction is not fully understood. In this paper the adsorption of amino acids was studied on the surface of brushite. Brushite was synthesized in the system of $\mathrm{Ca}\left(\mathrm{NO}_{3}\right)_{2}:\left(\mathrm{NH}_{4}\right)_{2} \mathrm{HPO}_{4}$ with equal concentrations. According to the results of XRD and IR spectroscopy it was established that precipitation was represented by the phase of brushite. It was implemented dynamic dissolution of the solid phase of brushite when the $\mathrm{pH}$ was varying. Equations of the kinetic graphs were obtained. It was investigated the adsorption of amino acids in a wide range of variation in their concentrations and the $\mathrm{pH}$ of the solution. It was considered the effect of $\mathrm{pH}$ on the maximum adsorption of amino acids on brushite. The results of IR spectroscopy confirmed adsorption. The solid phase of brushite was determined by the sign of the surface charge. The values of the sign of the surface charge of brushite were found to be positive. The values of the Gibbs free energy were calculated. There was revealed that the interaction of amino acids with the surface of the brushite was characterized by physical adsorption.
\end{abstract}

Keywords: brushite, adsorption, amino acid, dissolution, surface charge, solution, model of Langmuir, model of Freundlich.

\section{Introduction}

Biogenic and pathogenic mineral formations contain calcium phosphates. Biogenic formations are part of different organs and have different functions; they are genetically determined, their place in the body is strictly defined. Pathogenic mineral formations occur in the disruption of the functioning of the whole organism or its separate organs. It is known that in the early stages of the formation of pathogenic aggregates crystallize calcium hydrogen phosphate dihydrate, an analog of natural mineral brushite [1-3]. In the body of animals and humans brushite occurs mainly in conjunction with other calcium phosphates in the composition of pathogenic mineral formations, different places (teeth, salivary, kidney, and other stones) [4]. In the papers [5-11] the researchers describe that calcium phosphates have an excellent biological activity and have been widely used in bone reconstruction or orthopedic supplements, as the primary inorganic material of the composition of the hard tissues of the body. Interaction of organic and mineral components is important in such processes of biogenic crystallization, as the formation of bone matrix of mammals, as well as the emergence and growth of pathogenic entities. In one of the classifications, they are divided into two groups: low temperature ones and high temperature ones $[12,13]$. Hydroxylapatite (HA) and calcium hydrogen phosphate dihydrate (DCPD) $\mathrm{CaHPO}_{4} \cdot 2 \mathrm{H}_{2} \mathrm{O}$ are of greatest interest from number of the biocompatible lowtemperature calcium phosphates. DCPD in nature expressed in the mineral brushite is the most soluble of biocompatible calcium phosphates, $\mathrm{HA}$ is less soluble. At $60-100^{\circ} \mathrm{C}$ brushite gradually turns into $\mathrm{CaHPO}_{4}$ (DCPA) dicalcium phosphate. In [14] it is discussed the stability of calcium phosphates and the $\mathrm{Ca} / \mathrm{P}$ ratio. There are some assumptions, according to which the basis of the processes of mineralization lies in the adsorption interaction of free amino acids and associated protein molecules with inorganic components of biological liquids [2]. The mechanism of their interaction is not fully understood. In this regard, recent studies aimed at studying the regularities of adsorption of amino acids on the inorganic component of pathogenic neoplasms. The purpose of this work is the study of the peculiarities of adsorption of amino acids on brushite by varying the $\mathrm{pH}$ of the solution.

\section{Materials and methods}

The synthesis of brushite. It is carried out by deposition from aqueous solution at room temperature by the method of spontaneous crystallization according to the equation (1):

$$
\mathrm{CaX}_{2}+\mathrm{M}_{2} \mathrm{HPO}_{4}+2 \mathrm{H}_{2} \mathrm{O} \rightarrow \mathrm{CaHPO}_{4} \cdot 2 \mathrm{H}_{2} \mathrm{O} \downarrow+2 \mathrm{MX}
$$


The precipitate is obtained by mixing dilute solutions of calcium nitrate $\mathrm{Ca}\left(\mathrm{NO}_{3}\right)_{2} \cdot 4 \mathrm{H}_{2} \mathrm{O}$, and ammonium hydrogen phosphate $\left(\mathrm{NH}_{4}\right)_{2} \mathrm{HPO}_{4}$ with equal concentrations at room temperature $\left(22-25^{\circ} \mathrm{C}\right)$. When synthesis is carrying out a solution of $\mathrm{Ca}\left(\mathrm{NO}_{3}\right)_{2}$ was poured quickly to $250 \mathrm{ml}$ of a solution containing $\left(\mathrm{NH}_{4}\right)_{2} \mathrm{HPO}_{4}$ with equal concentrations $(50 \mathrm{mmol} / \mathrm{L})$. The total volume of the mixture is $500 \mathrm{ml}$. After mixing the solutions, the $\mathrm{pH}$ of the system was adjusted to a value of $5.50 \pm 0.05$ by using solutions of $\mathrm{NaOH}$ $(20 \%)$ and/or $\mathrm{HNO}_{3}(1: 1)$.

After the heterogeneous system settling for two days, the solution was filtered under the vacuum using a water jet pump. Some part of the supernatant liquid was selected for chemical analysis, measure the $\mathrm{pH}$ of the equilibrium solution. The filter cake was washed with water $(\mathrm{V}=50 \mathrm{ml})$ after filtration and dried in a drying cabinet at a temperature of $\sim 80^{\circ} \mathrm{C}$ to constant weight for the complete removal of free water, and then at room temperature (in a desiccators). The dried precipitate was transferred into a labeled container and weighed on an analytical balance.

It is determination of the sign of the charge of the particles of the sols of brushite by the method of capillary analysis. When a piece of filter paper immersed in water, thin wall paper was charged negatively. These allow determining the sign of the charge of the colloidal particles. Negatively charged particles rise through the capillaries.

It is the dynamic dissolution. A portion of the sample brushite a mass of $0.1000 \mathrm{~g}$ is taken on an analytical balance in a dry time glass. The study of the dissolution process is carried out at constant stirring of the solution. Using dedicated time intervals to note the amount of $\mathrm{pCa}$. At the end of the measurement indissoluble precipitate was filtered off through a folded filter, dried in a drying box at a temperature of $\sim 80^{\circ} \mathrm{C}$ to complete removal of chemically unbound water. The dried precipitate is transferred into a labeled container and weighed on an analytical balance.

We used the direct potentiometic method for $\mathrm{pH}$ measurements. The measurements were carried out in a glass beaker, which pre-processes. The measurement error is $\pm 0.01 \mathrm{pH}$ units.

Determination of the concentration of calcium ions in the experiment was performed by direct potentiometry using an ion-selective electrode and calibration schedule determined by the value of $\left[\mathrm{Ca}^{2+}\right]$.

Determination of phosphate ions was carried out by the molybdenum blue method (State Standard $18309-72$ on the KFK-2device using the red filter $\left(\lambda_{\text {ef }}=690 \mathrm{~nm}\right)$. The determination is repeated three times and the average values of optical densities were found to build a calibration curve: $\mathrm{D}=\mathrm{f}\left\{\mathrm{C}\left(\mathrm{PO}_{4}{ }^{3-}\right)\right\}$, calculate the regression equation. Error definitions are found within 2-4 Rel. \%.

It is X-ray diffraction(XRD). It is used to study the mineral (phase) composition of synthesized aqueous solid phases brushite. The diffracto grams were obtained by the «method of powder» for stationary DRON3X-ray apparatus [15]. Phase identification was performed using ASTM international indexes and tables [16]. The sensitivity of the XRD method for these measurements is $3 \%$.

The method of infrared spectroscopy was used for more information on the composition of the samples obtained. IR spectrum was obtained on the FSM 2201spectrophotometer. Mathematical processing of the data was carried out using statistical software Statistica 10 and Static2 from the statistical package Stat Soft. The sensitivity of the method of IR-spectroscopy for the measurement data was $<5 \%$.

It is the method of area measurement of the specific surface of synthetic calcium phosphates. Analysis of the specific surface of the samples according to the BET method (SBET-N2) was carried out using techniques of single-point standard gas adsorption equilibrium at an absolute pressure in the adsorption unit Sorbtometr, IK SB RAS (OSC SB RAS, Omsk). The limit of permissible relative error of measurement of the specific surface in the mode of multiple measurements is not more than $5 \%$.

The adsorption experiment. $0.5 \mathrm{~g}$ of Brushite sample was placed in a flask and the solution of amino acids was poured. The concentration of amino acids: $2,4,6,8,10,15,20,25$, and $30 \mathrm{mmol} / \mathrm{L}$ and $\mathrm{pH}$ range $5.00-8.00 \pm 0.05$ (except 6.50) in increments of 0.50 were varied. Shaking was carried out for 30 minutes, and then it was left for 48 hours. After the specified time the content of the flasks was filtered and there was determined the content of amino acids in the filtrate by the method of transfer of amino acids in a soluble copper salt and subsequent photometric determination, measurement of the $\mathrm{pH}$ after adsorption, determination of the mass of precipitation.

Determination of the concentration of amino acids in the experiment was assessed by photometric determination of amino acids. The essence of the method including determination of the concentration of amino acids used in the analysis is based on the conversion of amino acids into soluble copper salts and their subsequent photometric determination. KFK-2 photoelectric colorimeter was used for measurements. Determination of optical density of standard solutions is carried out in the wavelength interval that includes the 
value of $670 \mathrm{~nm}$. A calibration curve was built for measurements. Determining the unknown concentration of amino acids was performed using a calibration chart.

\section{Results and discussion}

1. The results of the synthesis of brushite crystals

The methods of XRD and IR spectroscopy establish that the precipitation obtained after 48 hours of crystallization was represented by the brushite phase (Fig. 1), belonging to the monoclinic crystal system (2Ө corresponds to $11.172,29.411$, and 35.419). The crystallite size was calculated to be equal to $\mathrm{D}=48.06 \mu \mathrm{m}$ [17], which was consistent with the data [3].

The IR spectrum of the samples contained the whole range of the bands characteristic for brushite (Fig. 2) and have a complex structure. It was noticed the presence of absorption bands of the stretching $\left(1135,1060,986 \mathrm{~cm}^{-1}\right)$ and bending $\left(653,578,527 \mathrm{~cm}^{-1}\right)$ vibrations of a group $\mathrm{HPO}_{4}{ }^{2-}$ as well as bands characteristic for vibrations of the water $3531,3484,1646 \mathrm{~cm}^{-1}$. The specific surface of brushite was calculated by the method of BET and its value was $9.0 \mathrm{~m}^{2} / \mathrm{g}$. Analysis of the supernatant liquid and calculation of the $\mathrm{Ca} / \mathrm{P}$ ratio showed that the $\mathrm{Ca} / \mathrm{P}$ of the synthesized brushite was equal to 1.02 , for a perfect brushite this value was $\mathrm{Ca} / \mathrm{P}=1.00$.

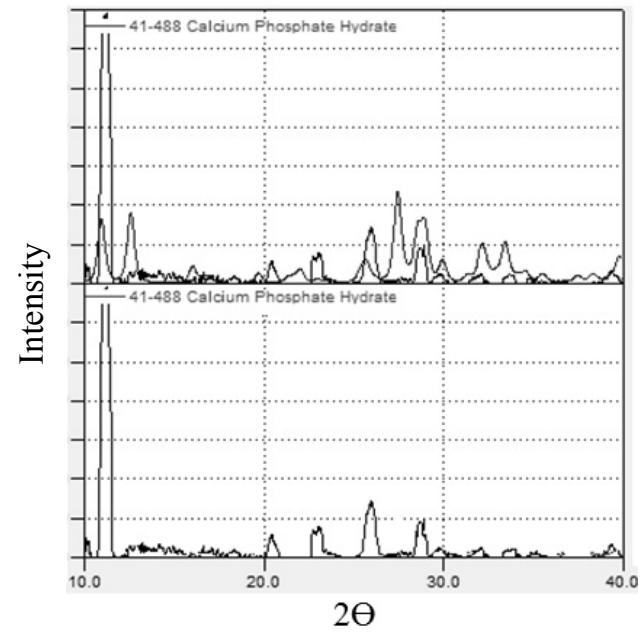

Figure 1. The diffraction pattern of the synthesized brushitesample at $\mathrm{pH}=5.50 \pm 0.05$ (48 hours)

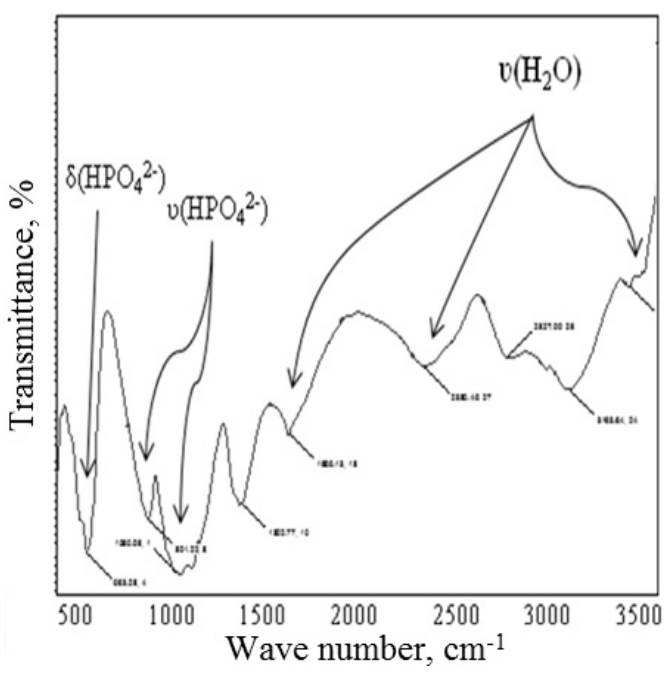

Figure 2. The IR spectrum of the brushitesample synthesized at $\mathrm{pH}=5.50 \pm 0.05$ (48 hours)

\section{The results of the study of the properties of brushite}

The method of dynamic dissolution is used to converse synthesized samples of brushite from the solid phase to the liquid phase, while varying the $\mathrm{pH}$.

The exponential dependence of the $\mathrm{pCa}$ from time to time is obtained, which corresponds to the reaction of the first order when the rate of change of the number of «active centers of dissolution» $(C(t))$ to dissolve the material is proportional to their number at the moment (1):

$$
\frac{d C(t)}{d t}=-k C(t)
$$

where the coefficient $k$ does not depend on time.

At this stage of dissolving, the rate of change of concentration decreases with time (2):

$$
\frac{d C(t)}{d t}=C_{m} b \cdot \exp (-b t)
$$

Therefore, the initial dissolution rate can be considered as a quantitative measure determined as the tangent of the slope of a linear plot a straight line constructed in the coordinates of the $\mathrm{pCa}=f(t)$ [2].

According to the obtained data, the dependence was constructed (Fig. 3). The kinetic curves were processed and the data are summarized in the Table 1. 


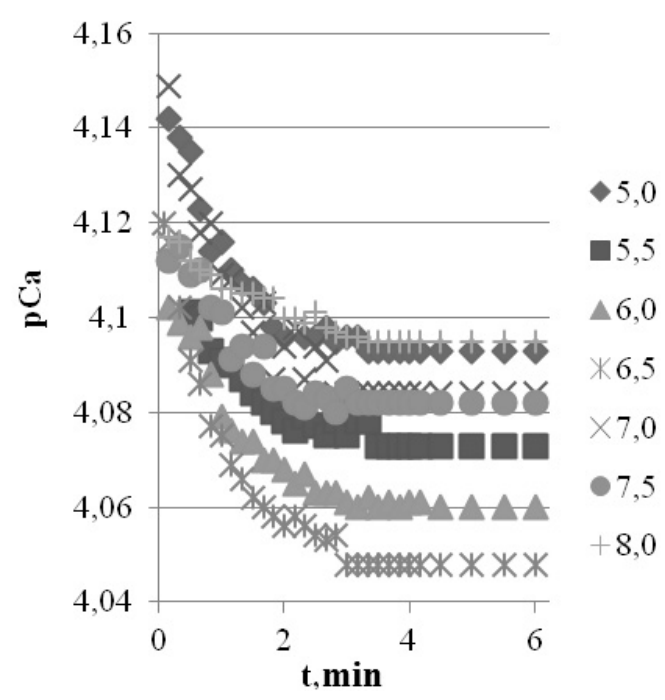

Figure 3. Kinetic curves of dissolution precipitation brushite in aqueous solution at different $\mathrm{pH}$ value

Ta b l e 1

Parameters of brushitedissolution depending on the variation of $\mathrm{pH}$ in an aqueous solution

\begin{tabular}{|c|c|c|c|c|}
\hline $\mathrm{pH}$ & Equation & $\mathrm{R}^{2}$ & $\mathrm{~K}, \mathrm{~s}^{-1}$ & $\mathrm{~V}, \mathrm{~mol}^{*}(1 * \min )^{-1}$ \\
\hline 5.00 & $\mathrm{pCa}=4.093+0.0425 \cdot \exp (-0.016 t)$ & 0.9632 & 0.016 & 0.960 \\
\hline 5.50 & $\mathrm{pCa}=4.073+0.0425 \cdot \exp (-0.014 t)$ & 0.9620 & 0.014 & 0.840 \\
\hline 6.00 & $\mathrm{pCa}=4.060+0.0464 \cdot \exp (-0.012 t)$ & 0.9795 & 0.012 & 0.720 \\
\hline 6.50 & $\mathrm{pCa}=4.048+0.0707 \cdot \exp (-0.011 t)$ & 0.9506 & 0.011 & 0.660 \\
\hline 7.00 & $\mathrm{pCa}=4.084+0.0627 \cdot \exp (-0.009 t)$ & 0.9880 & 0.009 & 0.540 \\
\hline 7.50 & $\mathrm{pCa}=4.082+0.0371 \cdot \exp (-0.005 t)$ & 0.9756 & 0.005 & 0.300 \\
\hline 8.00 & $\mathrm{pCa}=4.095+0.0233 \cdot \exp (-0.003 t)$ & 0.9488 & 0.003 & 0.180 \\
\hline
\end{tabular}

As seen that there is an inverse correlation between dissolution rate and $\mathrm{pH}$ of the solution, namely lowering the $\mathrm{pH}$ of the solution increases the dissolution rate. The calculation of the masses of the samples after dissolution allowed us to determine their loss (Table 2).

Table 2

\section{Mass loss of brushite samples when dissolved}

\begin{tabular}{|c|c|c|c|c|c|c|c|}
\hline $\mathrm{pH}$ & 5.00 & 5.50 & 6.00 & 6.50 & 7.00 & 7.50 & 8.00 \\
\hline$\Delta \mathrm{m}, \%$ & 27.0 & 22.6 & 18.0 & 17.2 & 16.8 & 13.0 & 8.7 \\
\hline
\end{tabular}

The results obtained agree well with the experimental data on the velocity of dissolution, and the maximum dissolution rate of the solid phase corresponds to the greatest loss. This fact was proved by determination of the composition of the samples after dissolution using XRD. Diffraction pattern shows that the phase composition of the phases has not changed.

The surface charge of the brushite solid phase by the method of capillary analysis at $\mathrm{pH}=5.00,6.50$, $8.00 \pm 0.05$ shows that the surface is charged positively.

\section{The results of adsorption experiment}

As a result of the adsorption experiment, isotherms of adsorption of amino acids to brushite were obtained (Fig. 4). Referring to the curves, it can be concluded that the adsorption reaches saturation. This allows for $\mathrm{Ca}=0.030 \mathrm{~mol} \times \mathrm{L}^{-1}$ to compare the values of adsorption while varying the $\mathrm{pH}$ of the solution to finding the values of maximum adsorption (Table 3 ). 


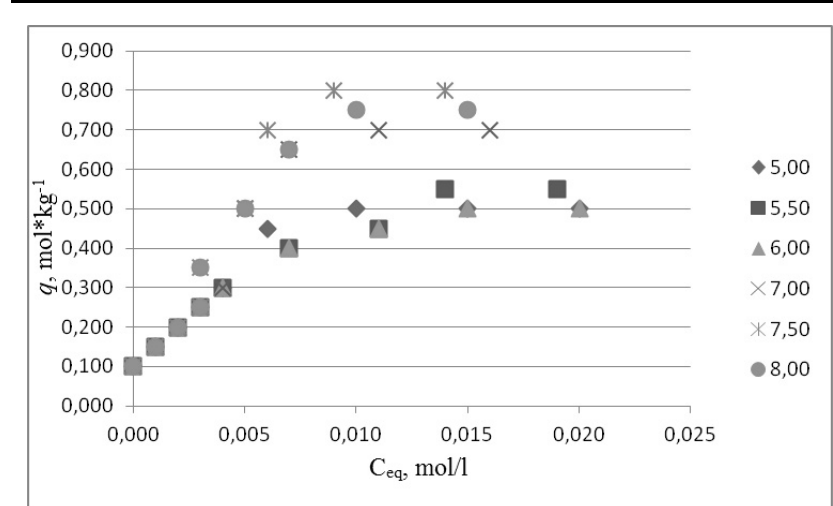

$a$

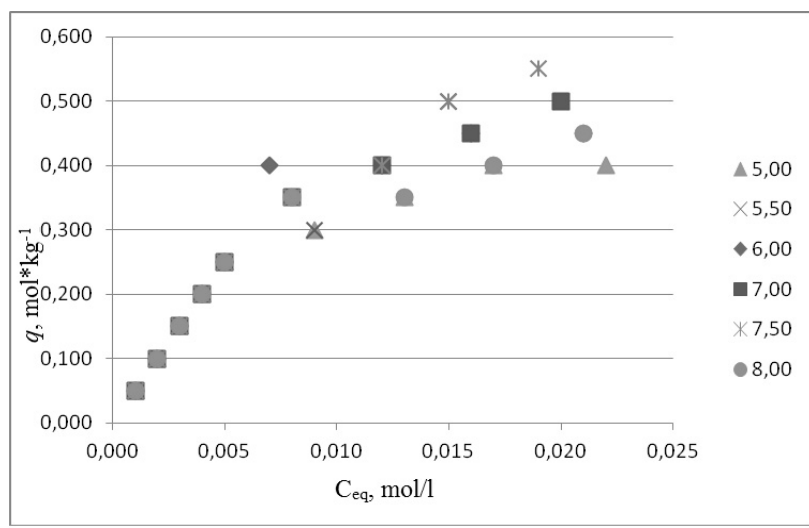

$c$

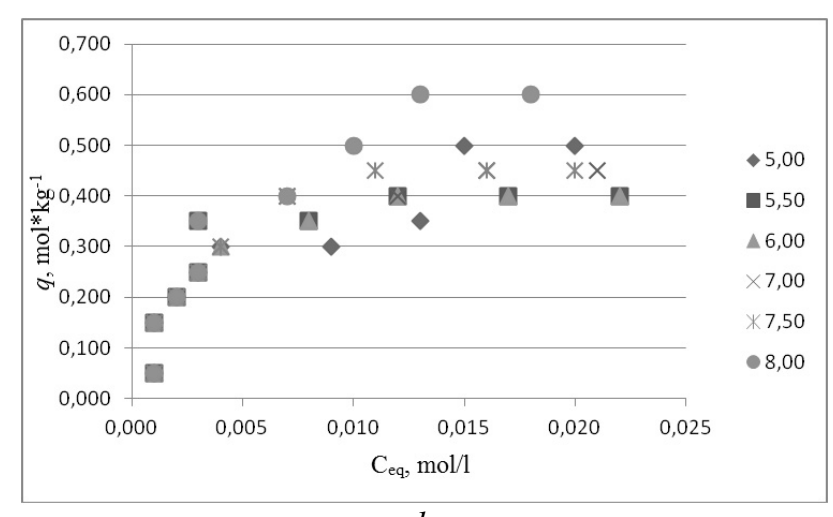

$b$

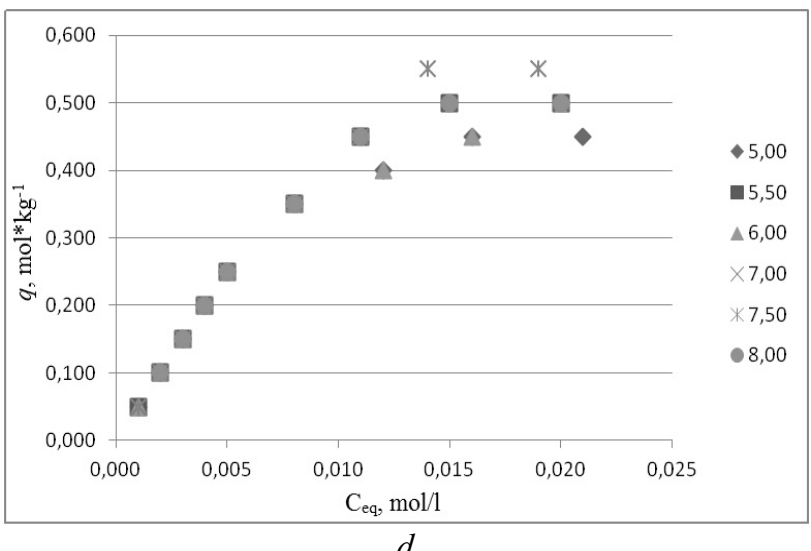

$a$ - glycine; $b$ - arginine; $c$ - alanine; $d$ - aspartic acid

Figure 4. Isotherms of adsorption of amino acids on brushite

Ta b le 3

The maximum adsorption of amino acids at varying $\mathrm{pH}, \mathrm{q}, \mathrm{mol} \times \mathrm{kg}^{-1}$

\begin{tabular}{|l|c|c|c|c|c|c|}
\hline \multirow{2}{*}{ Amino acid } & \multicolumn{5}{c|}{$\mathrm{pH}$} \\
\cline { 2 - 7 } & 5.00 & 5.50 & 6.00 & 7.00 & 7.50 & 8.00 \\
\hline Glycine & 0.500 & 0.550 & 0.500 & 0.700 & 0.800 & 0.750 \\
\hline Alanine & 0.400 & 0.500 & 0.450 & 0.500 & 0.550 & 0.450 \\
\hline Aspartic acid & 0.450 & 0.500 & 0.500 & 0.500 & 0.550 & 0.500 \\
\hline Glutamic acid & 0.750 & 0.750 & 0.800 & 0.700 & 0.850 & 0.800 \\
\hline Arginine & 0.500 & 0.400 & 0.400 & 0.450 & 0.450 & 0.600 \\
\hline
\end{tabular}

Maximum adsorption is characteristic for glycine, alanine, aspartic and glutamic acids at $\mathrm{pH}=7.50 \pm 0.05$, and for arginine at $\mathrm{pH}=8.00 \pm 0.05$. At given $\mathrm{pH}$ values of the solution, these amino acids are in charged ionic forms.

To determine the equation describing the adsorption, the experimental data were processed from the position of the Langmuir theory (3) and the Freindlich theory (4) (Table 4):

$$
q=\frac{q_{m} \cdot K_{L} \cdot C}{1+K_{L} \cdot C},
$$

where $q_{m}$ - is the limiting amount of adsorption, mol $\times \mathrm{kg}^{-1} ; K_{L}$ - is the adsorption equilibrium constant; $C$ - is equilibrium concentration of adsorbate, mol $\times \mathrm{L}^{-1}$.

$$
q=K_{F} \cdot C^{\frac{1}{n}}
$$

where $K_{F}$ - is coefficient of proportionality; $n$ - is exponent, $n<1$. 
$\mathrm{Tab}$ a 4

Equations described by the models of Freundlich and Langmuir, for adsorption of amino acids on brushite by varying the $\mathrm{pH}$ of the solution

\begin{tabular}{|c|c|c|c|c|c|c|}
\hline \multirow{2}{*}{ Amino acid } & \multirow{2}{*}{$\begin{array}{c}\mathrm{q}_{\max } \\
\operatorname{mol} \times \mathrm{kg}^{-1}\end{array}$} & \multirow{2}{*}{$\mathrm{pH}_{\max }$} & \multicolumn{2}{|c|}{ Equation model of } & \multicolumn{2}{|c|}{$\mathrm{R}^{2}$} \\
\hline & & & Langmuir & Freundlich & Langmuir & Freundlich \\
\hline Glycine & 0.800 & 7.50 & $q=1.128 \times \frac{221.1 \times C}{1+221.1 \times C}$ & $q=19.42 \times C^{0.704}$ & 0.6551 & 0.8993 \\
\hline Alanine & 0.550 & 7.50 & $q=1.133 \times \frac{65.10 \times C}{1+65.10 \times C}$ & $q=8.580 \times C^{0.681}$ & 0.9834 & 0.9809 \\
\hline Aspartic acid & 0.550 & 7.50 & $q=1.348 \times \frac{77.00 \times C}{1+77.00 \times C}$ & $q=11.81 \times C^{0.738}$ & 0.8803 & 0.9732 \\
\hline Glutamic acid & 0.850 & 7.50 & $q=0.952 \times \frac{396.6 \times C}{1+396.6 \times C}$ & $q=5.830 \times C^{0.576}$ & 0.8639 & 0.9368 \\
\hline Arginine & 0.550 & 8.00 & $q=0.946 \times \frac{99.50 \times C}{1+99.50 \times C}$ & $q=11.12 \times C^{0.671}$ & 0.8267 & 0.8005 \\
\hline
\end{tabular}

The obtained values of $q_{m}$ are adequate, as all practical values of $q$ are less than $q_{m}$. As can be seen from Table 4, adsorption of glycine, aspartic and glutamic acids has a good correlation in a linear model of Freundlich to a greater extent, however alanine and arginine, on the contrary, have a good correlation in the linear coordinates of the model of Langmuir.

It was further used to calculate the change of Gibbs energy according to the formula (5) (Table 5):

$$
\Delta G=-R T \cdot \ln K
$$

where $R$ - is the universal gas constant, $R=8.314 \mathrm{~kJ} /(\mathrm{Kmol} \times \mathrm{K}) ; K$ - is the constant of adsorption equilibrium.

T a b l e 5

The value of the Gibbs free energy for adsorption of amino acids, $-\Delta G, \mathrm{~kJ} \times \mathrm{mol}^{-1}$

\begin{tabular}{|l|c|c|c|c|c|c|}
\hline \multirow{2}{*}{\multicolumn{1}{|c|}{ Amino acid }} & \multicolumn{6}{c|}{$\mathrm{pH}$} \\
\cline { 2 - 7 } & 5.00 & 5.50 & 6.00 & 7.00 & 7.50 & 8.00 \\
\hline Glycine & 12.39 & 11.84 & 11.87 & 12.73 & 13.38 & 13.14 \\
\hline Alanine & 9.077 & 9.924 & 9.682 & 9.855 & 10.35 & 9.347 \\
\hline Aspartic acid & 9.617 & 10.17 & 9.855 & 10.17 & 10.76 & 10.17 \\
\hline Glutamic acid & 12.55 & 12.75 & 14.79 & 12.42 & 14.82 & 14.38 \\
\hline Arginine & 10.25 & 10.44 & 10.31 & 10.62 & 10.64 & 11.40 \\
\hline
\end{tabular}

As seen that the values of the Gibbs free energy correspond to the values of the maximum adsorption. The values of Gibbs free energy suggest that adsorption is, in fact, the physical adsorption.

Analysis of the surface charge of the solid phase of brushite after adsorption $\left(\mathrm{C}_{\mathrm{aa}}=4 \mathrm{mmol} / \mathrm{L}\right)$ at $\mathrm{pH}=5.00,6.50,8.00 \pm 0.05$ has shown that adding even small amounts of aspartic acid and glutamic acid, which are at the $\mathrm{pH}$ values of the solution in the form of negatively charged zwitterions, leads to the recharging of the surface. This can be explained by the process of adsorption of amino acids on the surface of brushite. When you add arginine at these conditions, which is in the form of positively charged zwitterions, recharge of the surface occurs. Adsorption of glycine and alanine does not result in recharge of the surface on the whole interval of $\mathrm{pH}$ of the solution, although under these conditions, they are consistent in three forms: a positively charged ion, neutral, zwitterion and negatively charged ion (Table 6).

The sign of the charge brushite in the presence of amino acids of a similar concentration

\begin{tabular}{|l|c|c|c|}
\hline \multirow{2}{*}{\multicolumn{1}{|c|}{ Amino acid }} & \multicolumn{3}{c|}{$\mathrm{pH}$} \\
\cline { 2 - 4 } & 5.00 & 6.50 & 8.00 \\
\hline Glycine & + & + & + \\
\hline Alanine & + & + & + \\
\hline Aspartic acid & - & - & - \\
\hline Glutamic acid & - & - & - \\
\hline Arginine & + & + & + \\
\hline
\end{tabular}


The results of IR spectroscopy confirm adsorption. The IR spectrum of the sample after the adsorption experiment (Fig. 5) have the bands in the region 2800 to $3000 \mathrm{~cm}^{-1}$ corresponding to the vibrations of C-H bonds in methylene groups of the organic component. Vibrations at $1650 \mathrm{~cm}^{-1}$ should be considered as an aggregate reflecting the fluctuation relations of $\mathrm{C}=\mathrm{O}, \mathrm{N}-\mathrm{H}, \mathrm{O}-\mathrm{H}$ in the molecules of amino acids and $\mathrm{OH}^{-}$ ions in the composition of brushite.

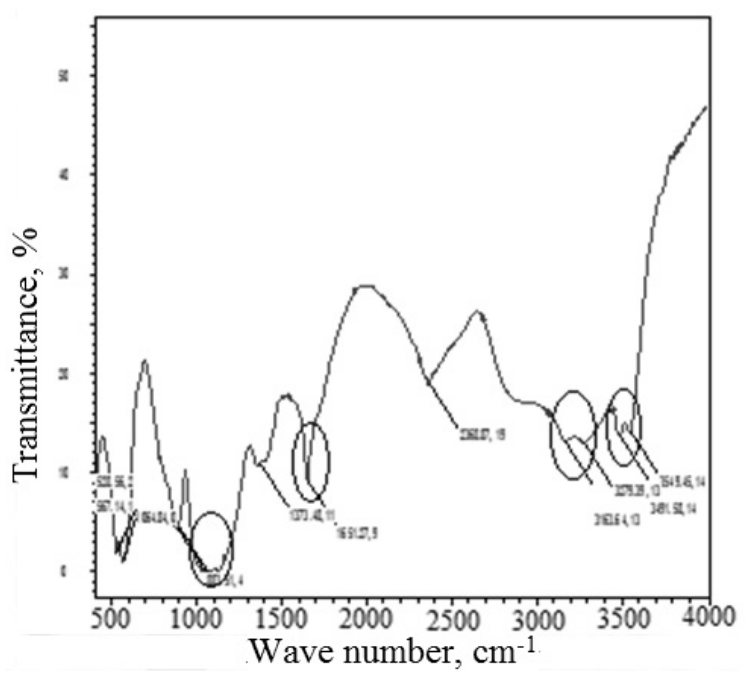

Figure 5. The IR spectrum of the sample after the adsorption experiment (48 hours)

Also, it was recorded the appearance of specific absorption bands related to vibrations of $\mathrm{N}-\mathrm{C}$ and $\mathrm{H}-\mathrm{N}$ bonds that occur in the regions 3500-3300, 1650-1500, 1360-1000 $\mathrm{cm}^{-1}$, which confirm the possibility of adsorption of amino acids on brushite.

\section{Conclusions}

1. It has been carried out the synthesis of brushite, the structure of which is confirmed by XRD and IR spectroscopy. The dynamic dissolution in aqueous solution with different $\mathrm{pH}$ value has been studied. It has been obtained that the values of the sign of the surface charge of brushite are positive.

2. The adsorption of amino acids on brushite has been investigated and it is shown that maximum adsorption occurs at $\mathrm{pH}=7.50 \pm 0.05$ for glycine, alanine, aspartic and glutamic acid, and for arginine at $\mathrm{pH}=8.00 \pm 0.05$.

3. Adsorption of glycine, aspartic and glutamic acids are outlined by the model of Freundlich, while for alanine and arginine adsorption is described by the model of Langmuir. The calculated values of the Gibbs free energy of adsorption are consistent with the values of the maximum adsorption.

The work was executed at the partial financial support of the Russian Foundation for basic research (grant No.15-29-04839 ofi_m and no 16-33-00684 mol_a).

\section{References}

1 Голованова О.А. Патогенные минералы в организме человека: монография / О.А. Голованова. - Омск: Изд-во ОмГУ, 2006. - 400 с.

2 Баринов С.М. Биокерамика на основе фосфатов кальция / С.М. Баринов, В.С. Комлев. - М.: Наука, 2005. — 204 с.

3 Солоненко А.П. Исследование влияния условий кристаллизации на физико-химические свойства химически модифицированных фосфатов кальция: дис. ... канд. хим. наук: 02.00.04 / А.П. Солоненко. — Омск, 2014. — $171 \mathrm{c}$.

4 Hsu Y.H. Mechanical characterization of dense calcium phosphate bioceramics with interconnected porosity / Y.H. Hsu, I.G. Turner, A.J. Miles // Mater. Sci. Mater. Med. — 2007. — Vol. 18. - P. 2319-2329.

5 Chow L.C. Calcium phosphate cements / L.C. Chow, E.D. Eanes // Basel. — 2001. — Vol. 18. — P. $17-42$.

6 Амерханова Ш.К. Релевантность определяется термодинамическими характеристиками образования кальцийсодержащих субстратов и сорбционных прорецептов с появлением глицерина (II) глицинов / Ш.К. Амерханова, О.А. Голованова, P.М. Шляпов // Вестник Омского ун-та. — 2015. — № 2. — P. 45-49.

7 Sepulveda P. Bioactive sol gel foams for tissue repair / P. Sepulveda, J.R. Jones, L.L. Hench // J. Biomed. Mater. Res. 2002. - Vol. 59. - P. 340-348. 
8 Silva G.A. Materials in particulate form for tissue engineering. II. Applications in bone. / G.A. Silva, O.P. Coutinho, P. Ducheyne, R.L. Reis // J. Regen. Med. - 2007. — Vol. 1. — P. 97-106.

9 Zhang Z. Effect of $\mathrm{pH}$ and ionic strength on competitive protein adsorption to air/water interfaces in aqueous foams made with mixed milk proteins / Z. Zhang, D.G. Dalgleish, H.D. Goff // Colloids Surf. B Biointerf. — 2004. — Vol. 34. — P. $113-121$.

10 Голованова О.А. Биоминеральные композиты из организма человека: теория, практика, перспективы / O.А. Голованова // Бутлеровские сообщения. - T. 24, № 3. - P. 113-122. ROI: jbc-01/11-24-3-113.

11 Герк С.А. Костный апатит человека - особенности химической структуры при патологии / С.А. Герк, О.А. Голованова // Бутлеровские сообщения. — 2011. — Т. 24, № 3. - P. 123-132. ROI: jbc-01 / 11-24-3-123.

12 Langstaff S. Resorbable bioceramics based on stabilized calcium phosphates. II. Evaluation of biological response / S. Langstaff, M. Sayer, T.J. Smith, S.M. Pugh // Biomaterials. — 2001. — Vol. 22. — P. 135-150.

13 Вересов А.Г. Химия неорганических биоматериалов на основе фосфатов кальция / А.Г. Вересов, В.И. Путляев, Ю.Д. Третьяков // Российский химический журнал. — 2004. - Т. 48, № 4. - С. 52-64.

14 Солоненко А.П. Термодинамическое моделирование процессов образования ортофосфата кальция / А.П. Солоненко // Бутлеровские сообщения. — 2011. - Т. 24, № 2. - P. 106-112. ROI: jbc-01 / 11-24-2-106.

15 Vallet-Regí M. Calcium phosphates as substitution of bone tissues / M. Vallet-Regí, J.M. González-Calbet // Prog. Solid Stat. Chem. - 2004. - Vol. 32. - P. 1-31.

16 Assimos D.G. Role of diet in the therapy of urolithiasis / D.G. Assimos, R.P. Holmes // Urol. Clin. North. Am. - 2000. Vol. 27, No. 2. - P. 255-268.

17 Bailly G.G. Effects of dietary fat on the urinary risk factors of calcium stone disease / G.G. Bailly, R.W. Norman, C. Thompson // Urology. - 2000. - Vol. 56, No. 1. - P. 40-44.

\title{
О.А. Голованова, К.К. Головченко
}

\section{Брушит бетінде аминқышқылдар сорбциясының физика-химиялық заңдылықтары}

\begin{abstract}
Кальций фосфаттары (КФ) физиогенді және патогенді минералды түзілімдердің құрамына кіреді. Адам және жануарлар ағзасында брушит негізінен басқа КФ бірге патогенді минералды түзілімдердің құрамында болады. Органикалық және минералды құраушыларының әрекеттесулері, сүйек кешендерінің қалыптасуы, патогенді түзілулердің тууы мен өсуі сияқты биогенді кристалдану үрдістерінде өте маңызды. Минералдану үрдістерінің негізінде бос және байланысқан амин қышқылдарының ақуыз молекулаларына биосұйықтардың бейорганикалық компоненттерімен әрекеттесуі жатыр деген бірнеше болжамдар бар. Бірақ олардың әрекеттесу механизмі әлі толық зерттелген жоқ. Жұмыста брушит бетінде аминқышқылдарының адсорбциясы зерттелген. Брушиттің синтезі $\mathrm{Ca}\left(\mathrm{NO}_{3}\right)_{2},\left(\mathrm{NH}_{4}\right)_{2} \mathrm{HPO}_{4}$ жүйесінде эквимолды концентрацияларымен бөлме температурасында $\left(22-25^{\circ} \mathrm{C}\right)$ жүргізілді. РФА және ИҚ-спектроскопия әдістерінің көмегімен тұнбалар брушит фазасымен құрылғаны анықталды. БЭТ әдісімен брушиттің 9,0 м²/г сыйымды беті есептелді. Брушит қатты фазасының динамикалық еруі рН әртүрлі мәндерінде жүргізілді. Кинетикалық қисықтар теңдеулері алынды. Ерітіндінің рН төмендегенде брушит қатты фазасының еру жылдамдығы артатыны анықталды. Амин қышқылдарының адсорбциясы олардың концентрациялары мен ерітінді $\mathrm{pH}$ кең аумағында зерттелді. Ерітіндінің $\mathrm{pH}$ брушиттегі амин қышқылдарының максималды адсорбциялануына әсері қарастырылды. ИҚ-спектроскопия нәтижелері адсорбция фактысын дәлелдеу үшін берілген. Брушит қатты фазасы бетінің заряды анықталды. Брушит беті зарядының мәні оң екені анықталды. Гиббс бос энергиясының мәндері есептеліп, амин қышқылдарының брушит бетімен әрекеттесуі физикалық адсорбциямен сипатталатыны анықталды.
\end{abstract}

Кілт сөздер: брушит, адсорбция, амин қышқылы, ерігіштігі, бетінің заряды, ерітінді, Ленгмюр моделі, Фрейндлих моделі.

\section{О.А. Голованова, К.К. Головченко}

\section{Физико-химические закономерности сорбции аминокислот на поверхности брушита}

Фосфаты кальция (ФК) входят в состав физиогенных и патогенных минеральных образований. В организме животных и человека брушит встречается главным образом совместно с другими ФК в составе патогенных минеральных образований. Взаимодействие органической и минеральной составляющих имеет важное значение в таких процессах биогенной кристаллизации, как формирование костного матрикса млекопитающих, а также зарождение и рост патогенных образований. Существует ряд предположений, согласно которым в основе процессов минерализации лежит адсорбционное взаимодействие свободных аминокислот и связанных в белковые молекулы с неорганическими компонентами биожидкостей. Однако механизм их взаимодействия до конца не изучен. В работе изучена 
адсорбция аминокислот на поверхности брушита. Проведен синтез брушита в системе $\mathrm{Ca}\left(\mathrm{NO}_{3}\right)_{2}:\left(\mathrm{NH}_{4}\right)_{2} \mathrm{HPO}_{4}$ с эквимолярными концентрациями при комнатной температуре $\left(22-25^{\circ} \mathrm{C}\right)$. По результатам РФА и ИК-спектроскопии установлено, что осадки представлены фазой брушита. Методом БЭТ рассчитали удельную поверхность брушита, равную $9,0 \mathrm{~m}^{2} /$ г. Осуществлено динамическое растворение твердой фазы брушита при варьировании $\mathrm{pH}$. Получены уравнения кинетических кривых. Показано, что с понижением $\mathrm{pH}$ раствора растет скорость растворения твердой фазы брушита. Исследована адсорбция аминокислот в широком интервале варьирования их концентраций и рН раствора. Рассмотрено влияние $\mathrm{pH}$ раствора на значение максимальной адсорбции аминокислот на брушите. Результаты ИК-спектроскопии приведены для подтверждения факта адсорбции. Проведено определение знака заряда поверхности твердой фазы брушита. Получено, что значение знака заряда поверхности брушита положительное. Осуществлен расчет значений свободной энергии Гиббса и выявлено, что взаимодействие аминокислот с поверхностью брушита характеризуется физической адсорбцией.

Ключевые слова: брушит, адсорбция, аминокислота, растворение, поверхностный заряд, раствор, модель Ленгмюра, модель Фрейндлиха.

\section{References}

1 Golovanova, O. A. (2006). Patohennyie mineraly v orhanizme cheloveka [Pathogenic minerals in a human body]. Omsk: OmSU Publ. house [in Russian].

2 Barinov, S.M., \& Komlev, V.S. (2005). Biokeramika na osnove fosfatov kaltsiia [The Bioceramics based on calcium phosphates]. Moscow: Nauka [In Russian].

3 Solonenko, A.P. (2014). Issledovanie vliianiia uslovii kristallizatsii na fiziko-khimicheskie svoistva khimicheski modifitsirovannykh fosfatov kaltsiia [Research of the influence of terms of crystallizing on the physicochemical properties of chemically modified calcium phosphates]. Candidate's thesis. Omsk [in Russian].

4 Hsu, Y.H., Turner, I.G., \& Miles, A.W. (2007). Mechanical characterization of dense calcium phosphate bioceramics with interconnected porosity. J. Mater. Sci. Mater. Med., 18, 2319-2329.

5 Chow, L.C., \& Eanes, E.D. (2001). Calcium phosphate cements. Basel, 18, $17-42$.

6 Amerkhanova, Sh.K., Golovanova, O.A., \& Shlyapov, R.M. (2015). Relevantnost opredeliaietsia termodinamicheskimi kharakteristikami obrazovaniia kaltsii soderzhashchikh substratov i sorbtsionnykh proretseptorov s poiavleniem hlitserina (II) hlitsinov [The relationship between the thermodynamic characteristics of the formation of calcium-containing substrate and sorption properties with respect to copper (II) glycinates]. Vestnik Omskoho Universiteta - Herald of Omsk University, 2, 45-49 [in Russian].

7 Sepulveda, P., Jones, J.R., \& Hench, L.L. (2002). Bioactive sol gel foams for tissue repair. J. Biomed. Mater. Res., 59, 340348.

8 Silva, G.A., Coutinho, O.P., Ducheyne P., \& Reis R.L. (2007). Materials in particulate form for tissue engineering. II. Applications in bone. J. Regen. Med., 1, 97-106.

9 Zhang, Z., Dalgleish, D.G., \& Goff, H.D. (2004). Effect of $\mathrm{pH}$ and ionic strength on competitive protein adsorption to air/water interfaces in aqueous foams made with mixed milk proteins. Colloids Surf. B Biointerf., 4, 113-121.

10 Golovanova, O.A. (2011). Biomineralnyie kompozity iz orhanizma cheloveka: teoriia, praktika, perspektivy [Biomineral composites from the human body: theory, practice, prospects]. Zhurnal Butlerovskie soobshcheniia - Butlerov communications, 24 3, 113-122. ROI: jbc-01/11-24-3-113[in Russian].

11 Gerk, S.A., \& Golovanova, O.A. (2011). Kostnyi apatit cheloveka - osobennosti khimicheskoi struktury pri patalohii [Bone apatite of the person - features of a chemical structure at a pathology]. Zhurnal Butlerovskie soobscheniia - Butlerov communications, 24, 3, 123-132. ROI: jbc-01/11-24-3-123 [in Russian].

12 Langstaff, S., Sayer, M., Smith, T.J., \& Pugh, S.M. (2001). Resorbable bioceramics based on stabilized calcium phosphates. II. Evaluation of biological response. Biomaterials, 22, 135-150.

13 Veresov, A.G., Putlyaev, V.I., \& Tretyakov, Yu.D. (2004). Khimiia neorhanicheskikh biomaterialov na osnove fosfatov kaltsiia [Chemistry of inorganic biomaterials based on calcium phosphates]. Rossiiskii khimicheskii zhurnal - Russian chemical journal, 48, 4, 52-64[in Russian].

14 Solonenko, A.P. (2011). Termodinamicheskoe modelirovanie protsessov obrazovania ortofosfata kaltsiia [Thermodynamic modeling of processes of formation of calcium orthophosphate]. Zhurnal Butlerovskie soobscheniia - Butlerov communications, 24(2), 106-112. ROI: jbc-01/11-24-2-106 [in Russian].

15 Vallet-Regí, M., \& González-Calbet, J.M. (2004). Calcium phosphates as substitution of bone tissues. Prog. Solid Stat. Chem., 32, 1-31.

16 Assimos, D.G., \& Holmes, R.P. (2000). Role of diet in the therapy of urolithiasis. Urol. Clin. North. Am., 27(2), $255-268$.

17 Bailly, G.G., Norman, R.W., \& Thompson, C. (2000). Effects of dietary fat on the urinary risk factors of calcium stone disease. Urology, 56(1), 40-44. 